\title{
Karakteristik ikan bulan-bulan (Megalops cyprinoides) dan potensinya sebagai tepung ikan
}

Characteristics of bulan-bulan fish (Megalops cyprinoides) and its potential as fish flour

\author{
Reni Tri Cahyani ${ }^{1 *}$, Stephanie Bija ${ }^{1)}$, Leny Tang Nga Sugi ${ }^{1)}$ \\ ${ }^{1}$ Program Studi Teknologi Hasil Perikanan, Universitas Borneo Tarakan, Kalimantan Utara \\ *Email: renitri_c@borneo.ac.id
}

Informasi Artikel:

Dikirim: 12/05/2020; ditinjau: 12/05/2020; disetujui: 30/30/2020

\begin{abstract}
Fish is very good for health because it contains various important nutrients such as protein, fat, and minerals. Fish flour can be added to food product to obtain physiological effects and improve the nutritional status of fortified foods. This study aims to examine the characteristics of Bulan-bulan fish (Megalops cyprinoides) and its potential as fish flour. This research was divided into two stages, namely characterization of the fresh fish and preliminary analysis of its potential as fish flour. The data obtained were analyzed descriptively. The results showed that the edible portion of fresh fish was only $42.81 \%$, whereas the remaining of $57.19 \%$ was processing waste. The fish had a high protein content of $21.43 \%$, fat content was $13.32 \%$, ash content was $12.80 \%$, moisture content was $42.29 \%$ and carbohydrate content was $10.19 \%$. The fish flour had powdered form; clean, normal, and bright appearance; bright brownish yellow color; quite dry and non-lumpy texture; and specific aroma. The yield of the fish flour was 22,75\%, whereas the protein content of the fish flour was 55.44\% which comply with the protein's requirement of quality II fish flour.
\end{abstract}

Keywords: Pasific tarpon, megalops cyprinoides, protein, proximate, fish flour

\begin{abstract}
ABSTRAK
Ikan diketahui sangat baik untuk kesehatan karena mengandung berbagai zat gizi penting seperti protein, lemak dan mineral. Tepung Ikan dapat ditambahkan pada produk pangan untuk mendapatkan efek fisiologis dan meningkatkan status gizi pangan terfortifikasi. Penelitian ini bertujuan untuk mengkaji karakteristik ikan Bulan-bulan (Megalops cyprinoides) dan potensinya sebagai tepung ikan. Penelitian ini dibagi menjadi dua tahap yaitu karakterisasi ikan Bulan-bulan segar dan analisis awal potensinya sebagai tepung ikan. Data yang diperoleh dianalisis secara deskriptif. Hasil penelitian menunjukkan bahwa edible portion pada ikan Bulan-bulan hanya sebesar $42,81 \%$, sisanya sebesar $57,19 \%$ merupakan processing waste. Ikan bulan-bulan mengandung protein yang cukup tinggi sebesar 21,43\%, kadar lemak sebesar 13,32\%, kadar abu sebesar 12,80\%, kadar air sebesar 42,29\% dan kadar karbohidrat sebesar 10,19\%. Tepung ikan Bulan-bulan yang dihasilkan berbentuk serbuk, kenampakan bersih, normal, cerah; warna kuning kecokelatan terang; tekstur cukup kering dan tidak menggumpal; serta bau spesifik jenis. Rendemen tepung ikan Bulan-bulan sebesar 22,75\%, sedangkan kadar protein tepung ikan Bulan-bulan sebesar 55,44\% di mana memenuhi persyaratan kadar protein tepung ikan kualitas II.
\end{abstract}

Kata kunci : Ikan bulan-bulan, megalops cyprinoides, protein, proksimat, tepung ikan 


\section{PENDAHULUAN}

Kesadaran masyarakat akan pentingnya konsumsi makanan yang bergizi cenderung meningkat dari tahun ke tahun. Kecenderungan tersebut terjadi seiring dengan meningkatnya pengetahuan masyarakat tentang penyakit tidak menular (PTM). PTM merupakan penyakit kronis yang tidak menular dari satu orang ke orang yang lain dan perkembangannya membutuhkan waktu yang cukup lama. Penyakit ini dapat disebabkan oleh kebiasaan merokok, konsumsi alkohol, kurangnya aktivitas fisik dan pola makan yang tidak sehat (Warganegara dan Nur, 2016). WHO pada tahun 2018 melaporkan bahwa PTM merupakan penyebab kematian paling banyak di dunia dengan tingkat prevalensi sebesar $71 \%$. PTM terbanyak didominasi oleh penyakit jantung dan pembuluh darah $(35 \%)$, penyakit kanker (12\%), diabetes (6\%) serta penyakit pernafasan kronis (6\%), sedangkan $15 \%$ sisanya disebabkan oleh PTM lainnya (KEMKES, 2019).

Ikan diketahui sangat baik untuk kesehatan karena mengandung berbagai zat gizi penting seperti protein, lemak dan mineral. Protein merupakan salah satu zat gizi pada ikan yang terdiri dari senyawa-senyawa bioaktif peptida yang memiliki efek fisiologis dalam tubuh yang belakang ini dikaitkan dengan kemampuannya dalam mencegah penyakit jantung. Senyawa-senyawa tersebut umumnya terdiri dari 3-20 asam amino yang mempunyai efek fisiologis antara lain sebagai antioksidan, antikoagulan, antibakteri dan antihipertensi (Susanto dan Fahmi, 2012). Fortifikasi pangan dengan menambahkan sumber protein hewani dapat dilakukan untuk mendapatkan efek fisiologis dan meningkatkan status gizi pangan terfortifikasi. Salah satu sumber protein hewani yang berpotensi digunakan untuk fortifikasi pangan adalah ikan Bulan-bulan (Megalops cyprinoides).

Ikan Bulan-bulan atau dalam bahasa inggris disebut Pasific Tarpon merupakan jenis ikan pelagis yang hidup di perairan pantai dan muara sungai (Mufarihat, Haryanti dan Munandar, 2019). Ikan Bulan-bulan termasuk hasil tangkapan sampingan (HTS) non ekonomis penting di perairan Tarakan, Kalimantan Utara. Umumnya, ikan-ikan non ekonomis penting kurang dimanfaatkan sehingga nilai jualnya sangat rendah. Pembuatan tepung ikan Bulan-bulan bertujuan untuk mempermudah pengaplikasian pada produk pangan dan mempermudah penyimpanan sebelum digunakan. Oleh karena itu, penelitian ini perlu dilakukan bertujuan untuk mengkaji karakteristik ikan Bulan-bulan (Megalops cyprinoides) dan potensinya sebagai tepung ikan.

\section{METODE}

\section{Bahan}

Bahan yang digunakan adalah ikan Bulan-bulan (Megalops cyprinoides) yang diperoleh dari Pasar Ikan Gusher, Kota Tarakan, Kalimantan Utara. Bahan kimia yang digunakan diantaranya diethyl ether, $\mathrm{Na}_{2} \mathrm{SO}_{4}$, percloric acid $52 \%$, anthrone reagen $0,1 \%$, larutan standar glukosa 10 ppm, $\mathrm{H}_{2} \mathrm{SO}_{4}$ pekat, $\mathrm{H}_{2} \mathrm{SO}_{4} 0,1 \mathrm{~N}, \mathrm{H}_{3} \mathrm{BO}_{3} 4 \%$, $\mathrm{NaOH} 40 \%$, tablet katalis kjedahl dan mixed indicator.

\section{Alat}

Alat yang digunakan diantaranya pisau, talenan, baskom, ayakan, grinder, stirrer hotplate, $\mathrm{pH}$ meter, timbangan, vortex, oven, alat detilasi, ekstraktor soxhlet, rotary evaporator, tanur pengabuan, desikator dan peralatan gelas lainnya.

\section{Metode}

Penelitian ini dibagi menjadi dua tahap. Tahap pertama adalah karakterisasi ikan Bulan-bulan segar. Parameter uji meliputi pengukuran proporsi, analisis kadar air metode oven, analisis kadar abu metode dry ashing, analisis kadar lemak metode soxhlet, analisis kadar protein metode Kjedahl dan analisis kadar karbohidrat metode clegg anthrone. Tahap kedua adalah analisis awal potensi ikan Bulan-bulan 
sebagai tepung ikan. Parameter uji meliputi rendemen dan kadar protein metode Kjedahl. Data yang diperoleh selanjutnya dianalisis secara deskriptif menggunakan teknik penyajian data secara visual dalam bentuk diagram maupun gambar. Selain itu, penyajian data juga dilakukan dalam bentuk tabel sehingga dapat diketahui kecenderungan tinggi atau rendahnya nilai hasil penelitian.

\section{HASIL DAN PEMBAHASAN}

\section{Proporsi ikan segar}

Proporsi merupakan perbandingan antara bagian-bagian dengan keseluruhan. Proporsi ikan terdiri dari bagian yang dapat dimakan (edible portion) berupa daging dan bagian yang dibuang (processing waste) berupa sisik, kepala, tulang dan kulit. Bagian daging ikan akan digunakan pada tahap selanjutnya. Proporsi ikan Bulan-bulan segar tersaji pada gambar 1 .

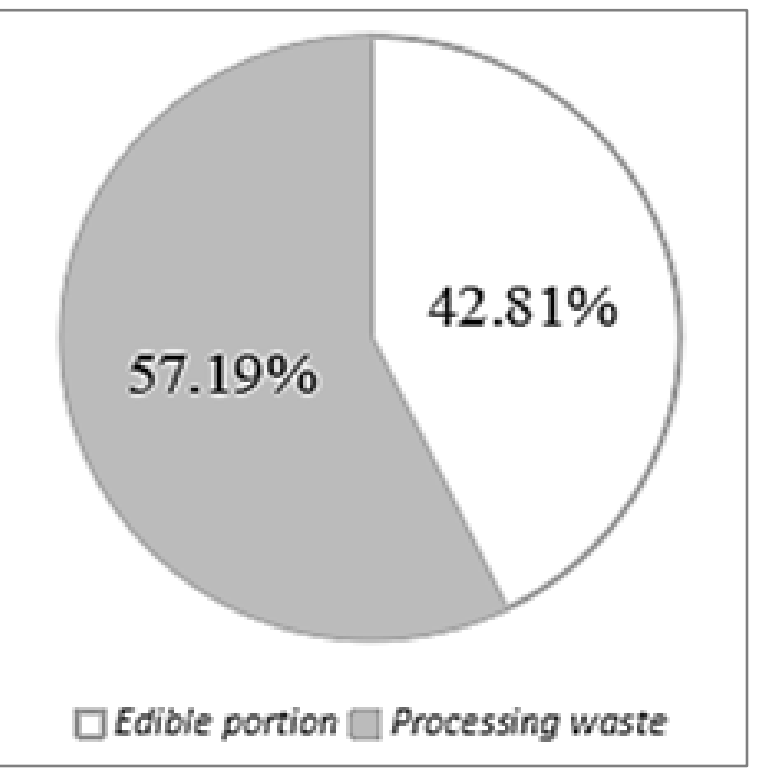

Gambar 1. Proporsi ikan bulan-bulan segar

Berdasarkan pengukuran proporsi pada Gambar 1, edible portion ikan Bulan-bulan hanya sebesar $42,81 \%$ sedangkan sisanya sebesar 57,19\% merupakan processing waste. Hal tersebut menunjukkan bahwa bagian yang dapat dimakan berupa daging lebih kecil dari bagian yang dibuang. Nilai edible portion didapatkan dari pemisahan daging dengan bagian lainnya seperti tulang dan kulit, sehingga nilai yang didapatkan dipengaruhi oleh cara pemisahannya. Menurut Asikin dan Kusumaningrum (2018), besar kecilnya nilai edible portion dipengaruhi oleh cara pemisahan daging dengan tulangnya. Selain itu, nilai edible portion juga dipengaruhi oleh panjang dan bobot ikan. Ikan dengan panjang dan bobot yang berbeda akan memberikan proporsi edible portion yang berbeda pula. Semakin panjang ikan, maka bobot ikan akan bertambah selanjutnya akan memperbesar pula nilai edible portion yang dihasilkan.

Cara pemisahan yang kurang tepat dapat memberikan nilai edible portion yang rendah sehingga mempengaruhi nilai ekonomis produk. Oleh sebab itu, edible portion sangat penting dalam industri pengolahan ikan. Menurut Sulistyanto, Darmanto dan Amalia (2015), ikan memberikan nilai edible portion yang berbeda-beda berdasarkan jenisnya. Namun, umumnya nilai edible portion pada ikan berkisar antara 45-50\%. Khusus untuk kelompok scromboidae, nilai edible portion berkisar antara 50-60\% dengan jumlah persentase daging merah antara 1-2\%.

\section{Komposisi kimia ikan segar}

Setiap bahan pangan memiliki komposisi kimia yang berbeda-beda. Analisis komposisi kimia daging ikan Bulan-bulan (Megalops cyprinoides) meliputi kadar air, kadar abu, kadar protein, kadar lemak dan kadar karbohidrat total. Komposisi kimia ikan Bulan-bulan segar tersaji pada tabel 1 . 
Tabel 1. Komposisi kimia daging ikan bulan-bulan segar

\begin{tabular}{clc}
\hline No & \multicolumn{1}{c}{ Komposisi kimia } & Nilai $(\boldsymbol{\%})$ \\
\hline 1. & Kadar air & 42,29 \\
2. & Kadar abu & 12,81 \\
3. & Kadar protein & 21,43 \\
4. & Kadar lemak & 13,32 \\
5. & Kadar karbohidrat & 10,19 \\
\hline
\end{tabular}

Kadar air mempengaruhi mutu dan daya simpan produk yang dihasilkan sehingga pengetahuan awal tentang kadar air dalam bahan pangan dapat digunakan sebagai dasar penentuan cara penanganan dan pengolahan yang tepat. Berdasarkan hasil analisis pada tabel 1, kadar air ikan Bulan-bulan sebesar 42,29\%. Pengukuran kadar air pada jenis ikan yang berbeda akan menunjukkan nilai yang berbeda pula. Menurut Hadinoto dan Idrus (2018), Kadar air daging ikan laut dipengaruhi oleh jenis dan status gizi ikan tersebut. Kadar air juga dipengaruhi oleh kondisi fisiologi ikan. Ikan dalam keadaan lapar atau sedang bertelur akan kehilangan banyak energi yang mengakibatkan peningkatan kadar air daging. Pada umumnya kadar air daging ikan berkisar antara 50-85\%.

Kadar abu mengindikasikan keberadaan mineral dalam bahan pangan. Kadar abu diukur berdasarkan kehilangan berat setelah pembakaran zat organik di mana titik akhir pembakaran dihentikan sebelum proses dekomposisi terjadi (Laboko, 2019). Berdasarkan hasil analisis pada tabel 1, kadar abu ikan Bulan-bulan adalah sebesar $12,81 \%$. Hal tersebut menunjukkan bahwa kandungan mineral pada daging ikan cukup tinggi. Menurut Palanikumar et al. (2014), daging ikan merupakan sumber mineral yang kaya. Ikan laut umumnya mengandung mineral lebih tinggi daripada ikan air tawar. Kandungan mineral dalam daging ikan berkontribusi terhadap total kadar abu. Variasi total kadar abu dalam ikan dipengaruhi oleh perilaku makan, lingkungan, ekosistem dan migrasi ikan.

Protein merupakan salah satu makronutrien yang terdiri dari asam amino esensial dan non esensial. Protein berperan dalam pertumbuhan dan perbaikan jaringan tubuh yang rusak. Kebutuhan protein dapat dipenuhi dari pangan berprotein tinggi seperti telur, daging dan ikan (Prihanto, 2017). Berdasarkan hasil analisis pada tabel 1, kadar protein ikan Bulan-bulan cukup tinggi yaitu sebesar 21,43\%. Menurut Hafiludin (2015), ikan dapat digolongan sebagai ikan berprotein tinggi dan berlemak rendah apabila ikan tersebut mengandung $>20 \%$ protein dan $<5 \%$ lemak. Perbedaan habitat, ukuran, jenis kelamin dan kondisi seksualitas dapat mempengaruhi kadar protein pada ikan. Emmanuel, Oshionebo dan Aladetohun (2011), menambahkan bahwa ikan Tarpon antlanticus (Megalops) mengandung protein sebesar 21,39-29,43\%. Perbedaan nilai protein pada ikan dapat dikaitkan dengan pola dan kebiasaan makan ikan serta kemampuannya dalam penyerapan dan konversi nutrisi penting dari makanan dan lingkungan tempat hidupnya.

Lemak ikan banyak mengandung asam lemak tak jenuh yang memiliki fungsi kesehatan. Berdasarkan hasil analisis pada tabel 1, kadar lemak ikan Bulan-bulan sebesar $13,32 \%$. Hal tersebut menunjukkan bahwa ikan Bulan-bulan termasuk ikan yang berlemak tinggi. Menurut Kantun, Malik dan Harianti (2015) ikan memiliki kadar lemak yang bervariasi tergantung dari umur, kondisi lingkungan dan variasi makanannya. Ikan dikatakan berlemak tinggi jika kadar lemaknya lebih dari 4\%. Menurut Abbey et al. (2016), ikan pelagis kecil merupakan sumber asam lemak omega-3 yang bermanfaat bagi kesehatan. Mengkonsumsi 100 gram ikan pelagis kecil seperti sarden dan ikan teri dapat memenuhi kebutuhan omega-3 tiap orang. Peningkatan pemanfaatan ikan dapat meningkatkan permintaan nutrisi dan mengurangi kerugian 
pascapanen. Hasil tangkapan samping umumnya bernilai ekonomis rendah namun tetep memiliki nilai nutrisi yang tinggi.

Karbohidrat merupakan salah satu zat gizi makro yang dibutuhkan sebagai sumber energi utama. Berdasarkan hasil analisis pada tabel 1, kadar karbohidrat ikan Bulan-bulan adalah sebesar 10,19\%. Menurut Arnesih et al. (2018), kadar karbohidrat dapat dijadikan penentu karakteristik bahan pangan karena keberadaannya dapat mempengaruhi rasa, warna dan tekstur produk. Fortifikasi dengan menggunakan bahan yang mengandung polisakarida dapat meningkatkan ketersediaan karbohidrat dalam produk.

\section{Pengolahan tepung ikan}

Pengolahan tepung ikan Bulan-bulan dilakukan di Laboratorium Teknologi Hasil Perikanan, Fakultas Perikanan dan Ilmu Kelautan, Universitas Borneo Tarakan. Pengolahan tepung ikan Bulan-bulan mengacu pada penelitian Adeleke dan Odedeji (2010) dengan modifikasi. Diagram alir pengolahan tepung ikan Bulan-bulan tersaji pada Gambar 2.

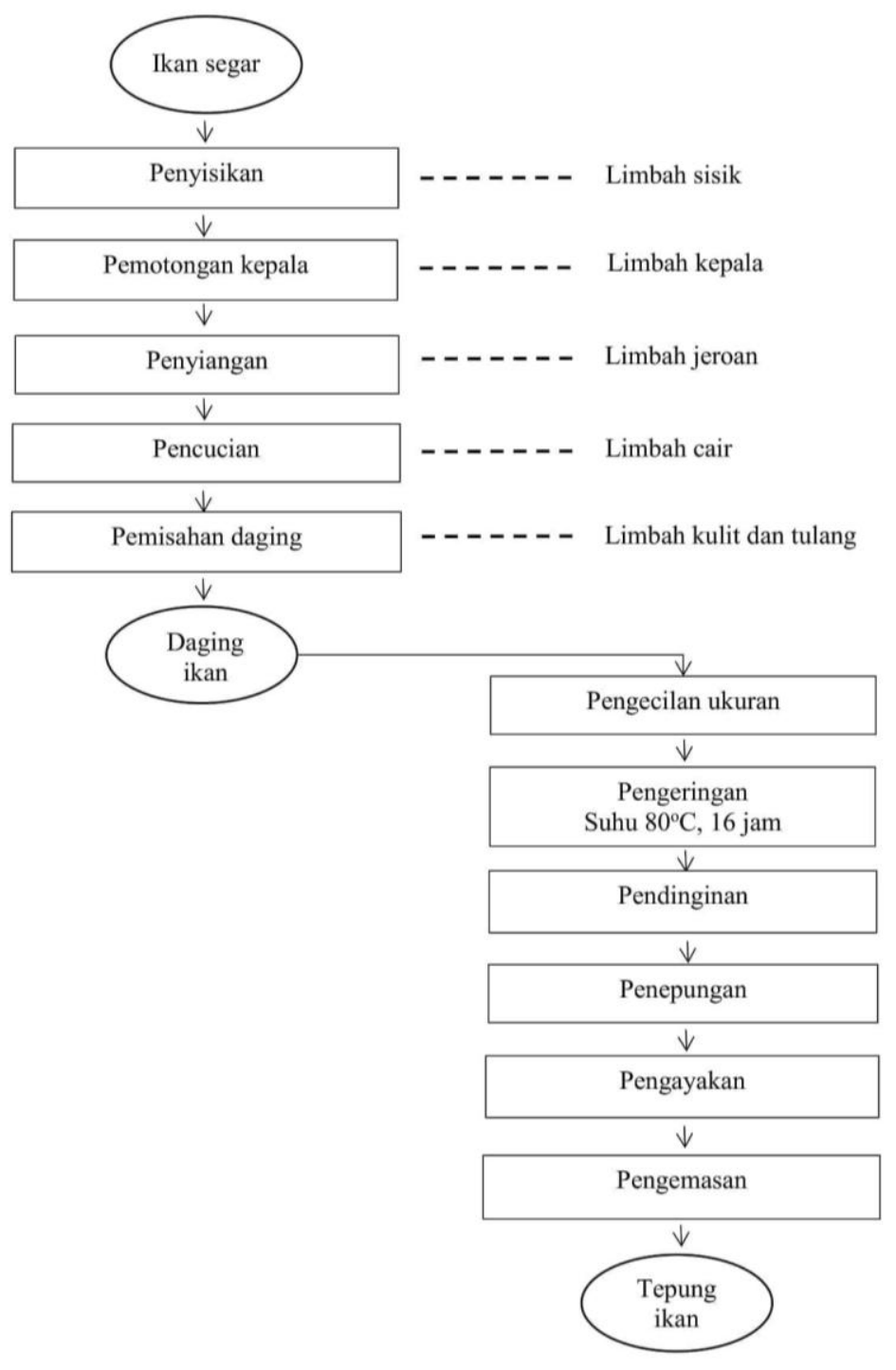

Gambar 2. Diagram alir pengolahan tepung ikan bulan-bulan

Pada tahap preparasi mula-mula ikan Bulan-bulan ditimbang beratnya. Berat ikan Bulan-bulan berkisar antara 215-241 gram. Selanjutnya, dilakukan penyisikan (Scales), pemotongan kepala (head removal), penyiangan (evisceration), pencucian (washing) dan pemisahan daging (meat separation). Setiap tahap dilakukan dengan 
menerapkan rantai dingin untuk mempertahankan kualitas daging ikan yang akan digunakan sebagai bahan baku dalam pembuatan tepung ikan. Tahap ini menghasilkan limbah berupa sisik, kepala, tulang, kulit dan limbah cair. Menurut Jahan et al. (2017). dalam pembuatan tepung ikan, sampel dicuci berulang kali untuk menghilangkan kotoran-kotoran yang ada di permukaan tubuh. Pemotongan kepala dan sirip serta pembuangan isi perut dilakukan untuk menghindari kontaminasi mikroba. Selanjutnya sampel dicuci kembali dengan air mengalir untuk menghilangkan sisa darah dan kotoran setelah proses penyiangan.

Daging ikan yang diperoleh kemudian ditimbang sebanyak 200 gram. Daging ikan selanjutnya diperkecil ukurannya dengan mencacah daging dengan pisau. Tujuan pencacahan adalah untuk memperluas permukaaan bahan sehingga dapat membantu mempercepat proses pengeringan. Ikan yang telah dicacah kemudian dimasukkan dalam oven untuk dilakukan pengeringan. Suhu pengeringan yang digunakan adalah $80^{\circ} \mathrm{C}$ selama 16 jam. Menurut Winangsih, Prihastanti dan Parman (2013), pengeringan menggunakan oven dengan suhu yang lebih tinggi dapat menghasilkan kadar air yang rendah dalam waktu singkat dibandingkan dengan pengeringan sinar matahari dan kering angin.

Setelah kering, ikan didinginkan pada suhu ruang. Selanjutnya dilakukan penepungan menggunakan grinder. Hasil penepungan kemudian ditimbang. Berat tepung ikan hingga tahap ini sebesar 52 gram. Setelah itu, dilakukan pengayakan dan penimbangan kembali untuk mengetahui berat produk akhir yaitu sebesar 45 gram. Tepung ikan kemudian dikemas dengan plastik PP (polypropylene) dan disimpan di tempat yang kering. Tepung ikan Bulan-bulan yang dihasilkan tersaji pada Gambar 3.

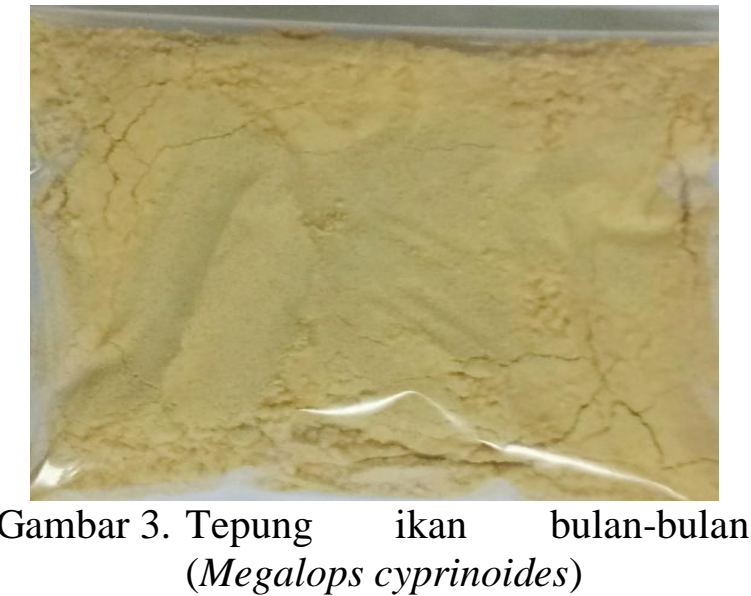

Tepung ikan Bulan-bulan yang dihasilkan berbentuk serbuk, kenampakan bersih, normal dan cerah, berwarna kuning kecokelatan terang serta memiliki tekstur yang cukup kering dan tidak menggumpal. Warna tepung ikan yang kecokelatan diduga karena kandungan lemak yang tinggi pada ikan Bulan-bulan sedangkan tekstur yang cukup kering diduga karena kadar air pada tepung ikan Bulan-bulan cukup rendah. Menurut Lunda, Ibrahim dan Suwarjoyowirayatno (2019), warna cokelat pada tepung ikan disebabkan oleh kandungan lemak yang teroksidasi selama proses pembuatan tepung ikan. Sedangkan menurut Anggriani, Pujaningsih dan Sumarsih (2019), proses pengeringan dengan oven dapat menyebabkan penguapan air hingga mencapai kadar air yang cukup rendah sehingga menghasilkan tepung ikan yang kering dan tidak menggumpal.

Tepung ikan Bulan-bulan yang dihasilkan memiliki bau spesifik jenis. Hal tersebut diduga akibat reaksi pemecahan senyawa asam amino dan lemak pada ikan. Menurut Hasanah, Lestari dan Adiningsih (2017), bau amis pada ikan dapat disebabkan oleh asam amino bebas dan asam lemak bebas yang terbentuk akibat serangkaian proses biokimia yang terjadi pada daging ikan. Fransiska dan Deglas (2017), menambahkan bahwa atribut bau merupakan salah satu atribut sensori yang dapat diamati dengan indera penciuman. Atribut bau juga dapat digunakan sebagai penanda adanya kerusakan pada produk. 


\section{Rendemen tepung ikan}

Rendemen dihitung dengan membandingkan berat produk akhir dengan berat awal daging ikan. Hasil perhitungan rendemen tepung ikan tersaji pada tabel 2 .

Tabel 2. Hasil perhitungan rendemen tepung ikan bulan-bulan

\begin{tabular}{lc}
\hline \multicolumn{1}{c}{ Perhitungan } & Nilai \\
\hline Berat Awal (g) & 200 \\
Berat Akhir $(\mathrm{g})$ & 45 \\
Rendemen $(\%)$ & 22,5 \\
\hline
\end{tabular}

Berdasarkan hasil perhitungan pada tabel 2, rendemen yang diperoleh dari proses pengolahan tepung ikan Bulan-bulan adalah $22,5 \%$. Besar kecilnya rendemen dapat dipengaruhi oleh metode pengolahan yang digunakan. Penggunaan suhu tinggi pada tahap pengeringan juga dapat meningkatkan penguapan air dalam bahan pangan sehingga menurunkan nilai rendemen produk akhir. Fatmawati dan Mardiana (2014), menambahkan bahwa proses penggilingan dan tingkat kesegaran bahan baku ikan yang digunakan juga dapat mempengaruhi nilai rendemen pada tepung ikan.

\section{Protein tepung ikan}

Tepung ikan merupakan sumber protein yang umum digunakan untuk fortifikasi pangan. Menurut Jayadi dan Rahman (2018), protein merupakan sumber asam amino esensial yang bermanfaat bagi kesehatan seperti fenilalanin, metionin, triptofan, isoleusin, treonin, histidin, leusin, lisin, dan valin. Protein hewani cenderung memiliki keseimbangan asam amino esensial yang lebih baik dari protein nabati.

Kadar protein tepung ikan yang diperoleh dalam penelitian ini adalah $55,44 \%$. Jika dibandingkan dengan kadar protein ikan segar maka kadar protein mengalami peningkatan. Hal ini disebabkan karena kadar air menurun selama proses pengeringan sehingga persentase zat gizi lain seperti protein menjadi meningkat. Menurut Yuarni, Kardiman dan Jamaluddin (2015), penggunaan suhu panas selama pengolahan dapat menurunkan kadar air yang menyebabkan kadar senyawa-senyawa lain seperti protein, karbohidrat, lemak dan mineral meningkat, tetapi senyawa vitamin dan zat warna akan menurun. Semakin kering suatu bahan maka semakin tinggi kadar proteinnya. Perbandingan kadar protein beberapa jenis tepung ikan dan standar SNI kadar protein tepung ikan tersaji pada tabel 3 .

Tabel 3. Perbandingan kadar protein beberapa jenis tepung ikan dan standar SNI

\begin{tabular}{|c|c|}
\hline Jenis Tepung & Nilai (\%) \\
\hline Ikan Bulan-bulan (Megalops cyprinoides) $^{(\mathrm{a})}$ & 55,44 \\
\hline Ikan Tuna (Thunnus sp) $)^{(\mathrm{b})}$ & 53,40 \\
\hline Ikan Nila (Oreochromis niloticus) ${ }^{(\mathrm{b})}$ & 40,55 \\
\hline Ikan Gabus (Channa striata) ${ }^{(\mathrm{c})}$ & 65,30 \\
\hline Ikan Kembung (Rastrelliger sp.) ${ }^{(\mathrm{d})}$ & 78,75 \\
\hline Tepung ikan kualitas $\mathrm{I}^{(\mathrm{e})}$ & 65 \\
\hline Tepung ikan kualitas II ${ }^{(\mathrm{e})}$ & 55 \\
\hline Tepung ikan kualitas III ${ }^{(\mathrm{e})}$ & 50 \\
\hline \multicolumn{2}{|l|}{${ }^{(a)}$ Hasil penelitian } \\
\hline \multicolumn{2}{|l|}{ (b) Handoyo dan Assadad (2016) } \\
\hline \multicolumn{2}{|l|}{${ }^{(c)}$ Wirawan, Alaydrus dan Nobertson (2018) } \\
\hline (d) Domili et al. (2020) & \\
\hline (e) BSN (2013) & \\
\hline
\end{tabular}


Berdasarkan hasil perbandingan protein tepung ikan pada tabel 3, tepung ikan Bulan-bulan memiliki protein yang cenderung lebih tinggi $(55,44 \%)$ dibanding ikan Tuna $(53,40 \%)$ dan ikan Nila $(40,55 \%)$, namun lebih rendah dari ikan Gabus $(65,30 \%)$ dan ikan Kembung (78,75\%). Perbedaan tersebut diduga dipengaruhi oleh kadar protein awal bahan baku dan metode yang digunakan dalam proses pengolahan tepung ikan. Menurut Sundari, Almasyhri dan Lamid (2015), metode yang digunakan dalam pengolahan bahan pangan dapat mempengaruhi nilai gizinya. Semakin tinggi suhu dan lama proses pengolahan suatu bahan pangan, maka semakin besar pula penurunan kadar protein yang terjadi pada bahan tersebut.

Apabila ditinjau dari kualitas tepung ikan yang tertuang dalam SNI 2715:2013, kadar protein yang dipersyaratkan sebesar $65 \%$ untuk kualitas I, 55\% untuk kualitas II, dan 50\% untuk kualitas III (BSN, 2013), Hal tersebut berarti tepung ikan Bulan-bulan yang dihasilkan dalam penelitian ini memenuhi persyaratan protein tepung ikan kualitas II.

\section{KESIMPULAN}

Ikan Bulan-bulan segar memiliki kadar protein cukup tinggi yaitu sebesar $21,43 \%$, kadar lemak sebesar 13,32\%, kadar abu sebesar 12,80\%, kadar air sebesar 42,29\% dan kadar karbohidrat total sebesar 10,19\%.dengan nilai edible portion sebesar $42,81 \%$. Analisis awal tentang potensi ikan Bulan-bulan sebagai tepung ikan menghasilkan tepung ikan berbentuk serbuk, kenampakan bersih, normal, cerah; warna kuning kecokelatan terang; tekstur cukup kering dan tidak menggumpal; serta bau spesifik jenis. Rendemen tepung ikan sebesar 22,75\%, sedangkan kadar protein pada tepung ikan Bulan-bulan yaitu sebesar $55,44 \%$ di mana memenuhi persyaratan kadar protein tepung ikan kualitas II. Ikan Bulan-bulan berpotensi sebagai tepung ikan yang dapat dijadikan sebagai sumber protein alternatif untuk fortifikasi pangan. Perbaikan proses pengolahan dimungkinkan untuk meningkatkan kadar protein pada tepung ikan Bulan-bulan.

\section{DAFTAR PUSTAKA}

Abbey, L., Amengor, M.G., Atikpo, M., Atter, A, \& Toppe, J. (2016). Nutrient content of fish powder from low value fish and fish byproducts. Food Science \& Nutrition, 5(3), 374-379. https://doi.org/10.1002/fsn3.402

Adeleke, R.O. \& Odedeji, J.O. (2010). Acceptability studies on bread fortified with tilapia fish flour. Pakistan Journal of Nutrition, 9(6), 531-534.

Anggriani, A.N., Pujaningsih, R.I. \& Sumarsih, S. (2019). Pengaruh perbedaan metode pengolahan dan level pemberian ekstrak daun kersen (muntingin calabura 1.) terhadap kualitas organoleptik tepung ikan rucah. Jurnal Sain Peternakan Indonesia, 14(3), 282-291. https://doi.org/10.31186/jspi.id.14.282 $-291$.

Arnesih, Junianto, Andriani, Y. \& Pratama, R.I. (2018). Characteristics of flavor powder of liquid waste mackerel tuna with wheat flour filler. Global Scientific Journal, 6(7), 276-281.

Asikin, A.N. \& Kusumaningrum, I. (2018). Karakteristik ekstrak protein ikan gabus berdasarkan ukuran berat ikan asal das mahakam kalimantan timur. Jurnal Pengolahan Hasil Perikanan Indonesia, 21(1), 137-142. https://doi.org/10.17844/jphpi.v21i1.2 1462

BSN. (2013). Standar Nasional Indonesia SNI 2715:2013.: Tepung Ikan - Bahan Baku Pakan Jakarta: Badan Standarisasi Nasional.

Domili, I., Labatjo, R., Ntau, L.A., Anasiru, M.A. \& Arbie, F.Y. (2020). Quality test of long-jawed mackerel (rastrelliger sp.) fish flour. Food Research, 4(3), 926-931. https://doi.org/10.26656/fr.2017.4(3).4 18 
Emmanuel, B.E., Oshionebo, C. \& Aladetohun, N.F. (2011). Comparative analysis of the proximate compositions of tarpon atlanticus and clarias gariepinus from culture systems in south - western nigeria. African Journal of Food, Agriculture, Nutrition and Development, 11(6), 5344-5359.

Fatmawati \& Mardiana. (2014). Analisa tepung ikan gabus sebagai sumber protein. Jurnal Ilmu Perikanan Octopus, 3(1), 235-243.

Fransiska \& Deglas, W. (2017). Pengaruh penggunaan tepung ampas tahu terhadap karakteristik kimia dan organoleptik kue stik. Jurnal Teknologi Pangan, 8(2), 171-179.

Hadinoto, S. \& Idrus, S. (2018). Proporsi dan kadar proksimat bagian tubuh ikan tuna ekor kuning (thunnus albacares) dari perairan maluku. Majalah BIAM, 14(02), 51-57.

Hafiludin. (2015). Analisis kandungan gizi pada ikan bandeng yang berasal dari habitat yang berbeda. Jurnal Kelautan, $8(1), 37-43$.

Handoyo, W.T. \& Assadad, L. (2016). Karakterisasi proses produksi dan kualitas tepung ikan di beberapa pengolah skala kecil. Prosiding Seminar Nasional Tahunan XIII Hasil Penelitian Perikanan dan Kelautan. Yogyakarta : UGM.

Hasanah, F., Lestari, N. \& Adiningsih, Y. (2017). Pengendalian senyawa trimetilamin (tma) dan amonia dalam pembuatan margarin dari minyak patin. Warta IHP, 34(2), 72-80.

Jahan, S.N., Bayezid, M.A., Islam, B., Siddique, M.A.B., Karmokar, P.K. \& Flowra, F.A. (2017). Biochemical quality assessment of fish powder. American Journal of Food Nutrition, 5(3),

110-114. https://doi.org/10.12691/ajfn-5-3-6

Jayadi, Y.I. \& Rahman, A. (2018). Analisis kandungan gizi makro pada ikan duo (penja) hitam dan putih sebagai pangan lokal kota palu. GHIDZA:
Jurnal Gizi dan Kesehatan, 2(1), 31-38.

Kantun, W., Malik, A.A. \& Harianti. (2015). Kelayakan limbah padat tuna loin madidihang thunnus albacares untuk bahan baku produk diversifikasi. JPHPI,18(3), 303-314. https://doi.org/10.17844/jphpi.2015.18 .3 .303

KEMKES. (2019). Buku pedoman manajemen penyakit tidak menular. Jakarta : Direktorat Pencegahan dan Pengendalian Penyakit Tidak Menular Kementerian Kesehatan.

Laboko, A.I. (2019). Pengaruh penambahan tepung ikan roa asap (hermihampus sp) terhadap mutu cookies. Jurnal Dunia Gizi, 2(1), 50-54.

Lunda, N., Ibrahim, M.N. \& Suwarjoyowirayatno. (2019). Pemanfaatan hasil samping pengolahan ikan peperek (leiognathus equulus) menjadi tepung ikan. J. Fish Protech, 2(1), 11-17.

Mufarihat, I.K., Haryati, S., \& Munandar, A. (2019). Karakteristik bontot dengan kombinasi daging ikan payus (elops hawaiiensis) dan ikan bulan bulan (megalops cyprinoides). JPHPI, 22(3), 476-482.

Palanikumar, M., Rubaannathai, A., Jeyashakila, R. \& Shanmugam, S.A. (2014). Proximate and major mineral composition of 23 medium sized marine fin fishes landed in the thoothukudi coast of india. J. Nutr. Food Sci, 4(1), 1-7. https://doi.org/10.4172/2155-9600.100 0259

Prihanto, A.A. (2017). Reaksi fisioko kimia produk perikanan tradisional. Malang: UB Press.

Sulistyanto, P., Darmanto, Y.S. \& Amalia, U. (2015). Karakteristik lem ikan dari tiga jenis ikan laut yang berbeda. Jurnal Ilmu dan Teknologi Kelautan Tropis, 7(1), 23-31.

Sundari, D., Almasyhuri \& Lamid, A. (2015). Pengaruh proses pemasakan terhadap komposisi zat gizi bahan 
pangan sumber protein. Media Litbangkes, 25(4),235-242.

Susanto, E. \& Fahmi, A.S. (2012). Senyawa fungsional dari ikan: aplikasinya dalam pangan. Jurnal Aplikasi Teknologi Pangan, 1(4), 95-102.

Warganegara, E. \& Nur. N.N. (2016). Faktor resiko perilaku penyakit tidak menular. Majority, 5(2), 88-94.

Winangsih, Prihastanti, E. \& Parman, S. (2013). Pengaruh metode pengeringan terhadap kualitas simplisia lempuyang wangi (zingiber aromaticum 1.). Buletin Anatomi dan Fisiologi, XXI (1), 19-25.

Wirawan, W., Alaydrus, S. \& Nobertson, R. (2018). Analisis karakteristik kimia dan sifat organoleptik tepung ikan gabus sebagai bahan dasar olahan pangan. Jurnal Sains dan Kesehatan, 1(9), 479-483. https://doi.org/10.25026 /jsk.v1i9.84

Yuarni, D., Kardiman \& Jamaluddin. (2015). Laju perubahan kadar air, kadar protein dan uji organoleptik ikan lele asin menggunakan alat pengering kabinet (cabinet dryer) dengan suhu terkontrol. Jurnal Pendidikan Teknologi Pertanian, 1(1), 12-21. 